\title{
Preservation of elemental and isotopic source identification of sedimentary organic matter
}

\author{
Philip A. Meyers \\ Department of Geological Sciences and Center for Great Lakes and Aquatic Sciences. The University of Michigan, Ann Arbor, \\ MI 48109-1063, USA
}

(Received March 25, 1993; revision accepted August 12, 1993)

\begin{abstract}
The amount and type of organic matter in the sediments of lakes and oceans contribute to their paleoenvironmental and paleoclimatological records. Only a small fraction of the initial aquatic organic matter survives destruction and alteration during sinking and sedimentation. Selective degradation modifies the character of the surviving small fraction of organic matter which becomes incorporated in bottom sediments. Organic matter alterations can continue to sub-bottom depths of hundreds of meters, corresponding to millions of years. Source and paleoenvironmental information nonetheless remains preserved in the molecular, elemental and isotopic compositions of organic matter. $\mathrm{C} / \mathrm{N}$ - and $\delta^{13} \mathrm{C}$-values of total organic matter, in particular, appear to retain paleoenvironmental information for multi-Myr time periods.
\end{abstract}

\section{Introduction}

Considerable difference exists between the concentration and character of biologically synthesized organic matter and that present in geological settings. Many processes impact organic matter in the relatively short time between its synthesis and its permanent burial in sediments. Early diagenesis begins in the photic zone of lakes and oceans, continues during the sinking of organic particles, and is intense in the bioturbated surface layer of sediments. Typically only a few percent of the initially biosynthesized organic matter consequently escapes remineralization and becomes buried in sediments (e.g., Suess, 1980; Wakeham et al., 1980; Knauer and Martin, 1981; Eadie et al., 1984; Emerson and Hedges, 1988).
An important component of many paleoceanographic and paleolimnologic investigations is to identify the sources of organic matter in sediments deposited at different times in the past. A critical question in view of the known decreases that occur to the quantity of sedimenting organic matter is "How accurately does the type of organic matter in sediments reflect the original sources?". Despite the extensive early diagenetic losses of organic matter in general and of some of its important biomarker compounds in particular, two of the bulk identifiers of organic matter sources - the $\mathrm{C} / \mathrm{N}$ ratio and the ${ }^{13} \mathrm{C} /{ }^{12} \mathrm{C}$ ratio - appear to undergo little change. This paper reviews examples of lacustrine and marine $\mathrm{C} / \mathrm{N}$ and $\delta^{13} \mathrm{C}$ sedimentary records and considers their paleoenvironmental significance. 


\section{2. $\mathrm{C} / \mathrm{N}$ and $\delta^{13} \mathrm{C}$ identifiers of organic matter source}

$\mathrm{C} / \mathrm{N}$ ratios have often been used to distinguish between algal and land-plant origins of sedimentary organic matter (e.g., Prahl et al., 1980; Premuzic et al., 1982; Ishiwatari and Uzaki, 1987; Jasper and Gagosian, 1990). Algae typically have atomic $\mathrm{C} / \mathrm{N}$ ratios between 4 and 10 , whereas vascular land plants have $C / N$ ratios of $\geqslant 20$ (Table 1). This distinction arises from the absence of cellulose in algae and its abundance in vascular plants. Selective degradation of organic matter components during early diagenesis has the potential to modify $\mathrm{C} / \mathrm{N}$ ratios of organic matter in sediments. The lowering of $\mathrm{C} / \mathrm{N}$ ratios has been observed in soils (e.g., Sollins et al., 1984), where it involves the microbial immobilization of nitrogenous material accompanied by the remineralization of carbon. The $\mathrm{C} / \mathrm{N}$ source signal appears to be preserved, however, in subaqueous sediments. Vascular plant debris isolated from a coastal marine sediment in which the bulk $\mathrm{C} / \mathrm{N}$ was 15 had $\mathrm{C} / \mathrm{N}$-values ranging between 30 and 40, which are characteristic of cellulosic plants (Ertel and Hedges, 1985).

Carbon isotopic ratios are useful to distinguish between marine and continental plant sources of sedimentary organic matter and to identify organic matter from different types of land plants. Most photosynthetic plants incorporate carbon into organic matter using the $\mathrm{C}_{3}$ Calvin pathway which biochemically discriminates against ${ }^{13} \mathrm{C}$ to produce a $\delta^{13} \mathrm{C}$ shift of $\sim$ $-20 \%$ from the isotope ratio of the inorganic carbon source. Some plants use the $\mathrm{C}_{4} \mathrm{Hatch}-$ Slack pathway, which creates a diffusional isotope shift of $\sim-7 \%$. Organic matter produced from atmospheric $\mathrm{CO}_{2}\left(\delta^{13} \mathrm{C} \approx-7 \% 0\right)$ by land plants using the $\mathrm{C}_{3}$ pathway consequently has an average $\delta^{13} \mathrm{C}$-value of $\sim-27 \%$ (PDB) and by those using the $\mathrm{C}_{4}$ pathway $\sim-14 \%$ (cf. O'Leary, 1988). Freshwater algae utilize dissolved $\mathrm{CO}_{2}$, which is usually in isotopic equilibrium with atmospheric $\mathrm{CO}_{2}$. As a consequence, the carbon isotopic composition of lake-derived organic matter is typically indistinguishable from that of organic matter from the surrounding wa- tershed (e.g., Nakai, 1972; Benson et al., 1991; Table 1). The source of inorganic carbon for marine algae is dissolved bicarbonate, which has a $\delta^{13} \mathrm{C}$-value of $\sim 0 \%$. Marine organic matter consequently typically has $\delta^{13} \mathrm{C}$-values between -22 and $-20 \%$ (Table 1 ). The $\sim 7 \%$ difference between organic matter produced by $\mathrm{C}_{3}$ land plants and marine algae has successfully been used to trace the sources and distribution of organic matter in coastal ocean sediments (e.g., Hunt, 1970; Newman et al., 1973; P.J. Gearing et al., 1977). However, the isotopic source signal can become complicated in coastal areas which receive contributions of organic matter from algae and both $\mathrm{C}_{3}$ and $\mathrm{C}_{4}$ vascular plants (e.g., Fry et al., 1977). In these areas, and also in lakes, addition of $\mathrm{C} / \mathrm{N}$ ratios to $\delta^{13} \mathrm{C}$ determinations allows better discrimination of organic matter sources.

Four distinctive suites of $\mathrm{C} / \mathrm{N}$ - and $\delta^{13} \mathrm{C}$-values in plants are evident in Fig. 1. These comibinations of elemental and carbon isotopic values can be used to distinguish sources of organic matter in sediments and in settling particles. A particular benefit to using these bulk identifiers of organic matter origins is that they represent the whole mixture of organic matter components. In contrast, biomarker molecules typically are a very small fraction of the total mixture and

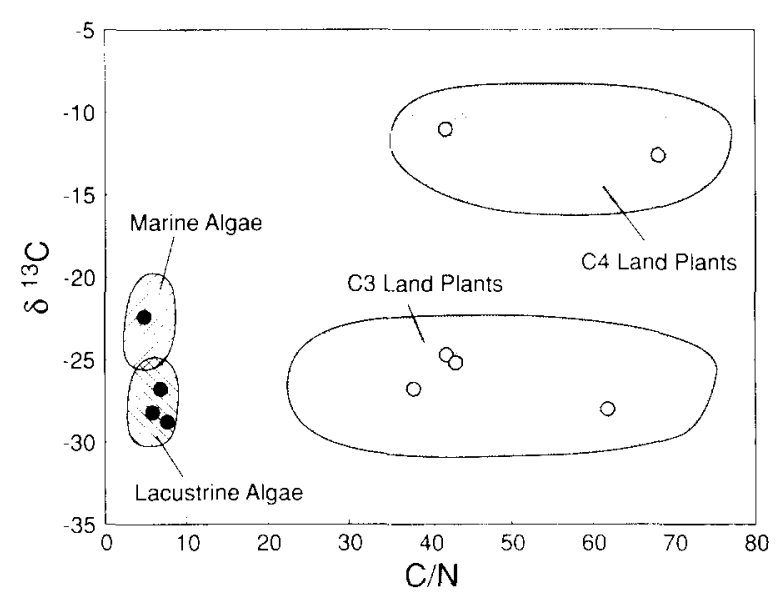

Fig. 1. Distinctive source combination s atomic $\mathrm{C} / \mathrm{N}$ ratios and organic $\delta^{13} \mathrm{C}$-values of marine algae, lacustrine algae, $\mathrm{C}_{3}$ land plants and $\mathrm{C}_{4}$ land plants. Sources of data for individual plant samples are given in Table 1 . 
Table 1

Compilation of representative atomic $\mathrm{C} / \mathrm{N}$ ratios and organic $\delta^{13} \mathrm{C}$-values of different types of primary organic matter sources to sediments of lakes and oceans

\begin{tabular}{llll}
$\begin{array}{l}\text { Organic matter } \\
\text { source }\end{array}$ & Location & $\mathrm{C} / \mathrm{N}$ & $\begin{array}{l}\delta^{13} \mathrm{C} \\
(\% 0 \text { vs. PDB })\end{array}$ \\
\hline
\end{tabular}

$C_{3}$ land plants:

\section{Willow leaves \\ Poplar leaves \\ Pinyon pine needles \\ White spruce needles \\ Mangrove leaves \\ Palm fronds \\ $C_{4}$ land plants:}

Salt grass

Tumbleweed

Blood grass

Wild millet

\section{Lake algae:}

Mixed plankton

Mixed plankton

Mixed plankton

Marine algae:

Mixed diatoms

Mixed

nannoplankton

Mixed plankton

Mixed plankton
Walker Lake, Nevada, U.S.A.

Walker Lake, Nevada, U.S.A.

Walker Lake, Nevada, U.S.A.

Michigan

Penang, Malaysia

Lake Bosumtwi, Ghana

Walker Lake, Nevada, U.S.A.

Walker Lake, Nevada, U.S.A.

Lake Bosumtwi, Ghana

Lake Bosumtwi, Ghana

Walker Lake, Nevada, U.S.A.

Pyramid Lake, Nevada,

U.S.A.

Lake Michigan, North

America

Narragansett Bay, Rhode Island, U.S.A.

Narragansett Bay, Rhode

Island, U.S.A.

Penang, Malaysia

Dabob Bay, Washington,

U.S.A.

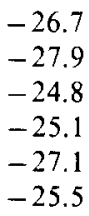

[I]

[I]

[I]

[2]

[3]

[4]

[1]

[1]

[4]

[4]

-14.1
-12.5
-11.1
-10.8

[1]

$-26.8$

[6]

$-=$ not determined.

a References: [ $I]=$ Meyers (1990); [2] =P.A. Meyers (unpuplished data, 1992); [3]= Rodelli et al. (1984); [4]=Talbot and Johanessen (1992); [5] =J.N. Gearing et al. (1984); [6]=Prahl et al. (1980).

may not be representative of the whole, even though they convey very useful information about their individual sources and diagenesis pathways.

\section{Alterations of organic matter during sinking}

Sediment traps have been employed in lakes and oceans to study changes in compositions of organic matter during sinking to bottom sediments. These studies have shown that substan- tial degradation of both total organic matter and of specific components occurs during sinking. Results from lakes emphasize how rapidly change can occur during sinking relatively short distances; only $6 \%$ of the initial algal organic matter survives to reach Lake Michigan (North America) bottom sediments in $100 \mathrm{~m}$ of water (Eadie et al., 1984).

The molecular source character of organic matter can change during sinking and incorporation into sediments. Fluxes of marine algal biomarkers at water depths of $5000 \mathrm{~m}$, for in- 
stance, are less than $1 \%$ of their photic zone fluxes (Wakeham and Lee, 1989). In Lake Michigan, the proportions of algal fatty acids and alcohols similarly decrease at progressively deeper sediment trap depths (Meyers et al., 1984a). Fatty acid decomposition rates calculated from sediment trap compositions show that $n-\mathrm{C}_{16}$ degrades $\sim 10$ times faster than $n-\mathrm{C}_{30}$ (Meyers and Eadie, 1993). Preferential degradation of algal biomarkers continues in bottom sediments. Kawamura et al. (1987) found that distributions of $n$-alkanes in surficial sediments from Lake $\mathrm{Ha}$ runa, Japan, were depleted in $n-\mathrm{C}_{17}$ relative to the hydrocarbon contents of sediment trap material in this lake. As a consequence of the selective degradation of algal biomarker molecules, land-plant lipids dominate the biomarker contents of modern sediment from Lake Vechten in The Netherlands, although carbon budgets indicate that land contributions comprise a small part of the original input to this lake system (Goossens et al., 1989).

Comparison of the organic matter $\mathrm{C} / \mathrm{N}$ ratios and $\delta^{13} \mathrm{C}$-values of plankton, sediment trap contents and surficial sediment in Lake Michigan suggests that these bulk parameters retain source information despite large decreases in the total amount of organic matter during sinking (Fig. 2 ). Organic carbon concentrations diminish by a factor of 10 between plankton and the lake bottom, yet little difference is evident between the initial and final $\mathrm{C} / \mathrm{N}$ or carbon isotopic ratios. Considerable variation is evident, however, in the $\mathrm{C} / \mathrm{N}$-values of the sinking organic matter. These changes in organic matter elemental composition agree with observed changes in biomarker compositions that show selective losses of algal components in the upper water column and apparent lateral input of algal organic matter at deeper depths (Meyers and Eadie, 1993). These changes apparently reflect different diagenetic processes at different depths. The isotopic compositions are less sensitive to selective diagenesis, principally because the isotopic signatures of algal and land-plant organic matter are typically the same in lakes (Table 1; Fig. 1).

The susceptibility of organic matter to diagenetic change during the relatively short time that

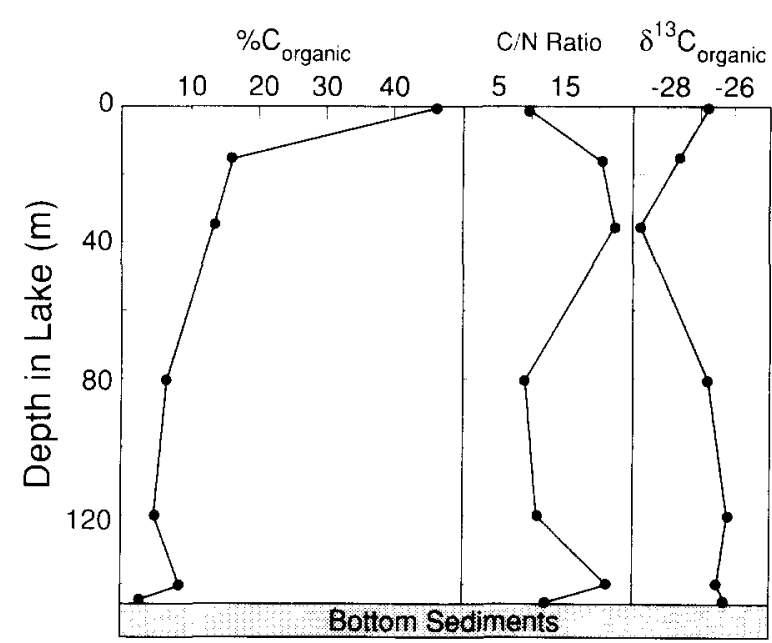

Fig. 2. Organic carbon concentrations, atomic $\mathrm{C} / \mathrm{N}$ ratios and carbon isotopic signatures in phytoplankton, sediment traps at five depths and surficial sediments in Lake Michigan, North America. Organic carbon concentrations decrease by a factor of 10 , but $\mathrm{C} / \mathrm{N}$ and isotopic ratios are virtually unchanged between phytoplankton and sediment values. From Meyers and Eadie (1993).

is needed to sink to the bottom of lakes and oceans suggests that many more changes can occur during the much longer times that organic matter resides in sediments. A variety of different carbohydrates, amino compounds, lipids and derived materials constitute sedimentary organic matter. Some of these organic substances are more reactive than others, providing the opportunity for selective diagenesis to modify the source character of organic matter. The preferential degradation of algal biomarkers in sediment traps and lakes (e.g., Meyers et al., 1984a; Kawamura et al., 1987; Goossens et al., 1989; Wakeham and Lee, 1989) is an apt example of diagenetic source character modification. These diagenetic modifications of specific components of organic matter have raised important questions about the reliability of bulk organic matter parameters as source indicators.

\section{Alteration and preservation of organic matter source records in lake sediments}

Sediment trap studies show that the proportions of algal and land-derived organic matter can 
be identified by $\mathrm{C} / \mathrm{N}$ and carbon isotopic ratios. A survey of lake studies reveals that bulk source character is preserved over the longer periods of time during which organic matter resides in sediments, even though organic matter may continue to be degraded.

\subsection{Sedimentary organic matter record in Mangrove Lake (Bermuda)}

Mangrove Lake is a small saline lake located close to the Bermuda shoreline. No permanent streams flow into the lake; its principal source of water is from seawater seepage through the permeable limestone between it and the sea. Algal production is the main source of organic matter to the present-day lake, although mangroves surround it. The sedimentary sequence of Mangrove Lake consists of peat overlain by sapropels and records a progression from a late Pleistocene freshwater bog to a freshwater lake and finally to a saline lake as sealevel rose in the Holocene (Fig. 3 ). The transition from freshwater to salt-water conditions occurred $\sim 4 \mathrm{kyr}$ ago (Hatcher et al., 1982). The sediments are rich in organic matter throughout the sequence, containing between $18 \%$ and $40 \%$ organic carbon.

Organic $\mathrm{C} / \mathrm{N}$-values approximate the changes in organic matter sources to the sediments of

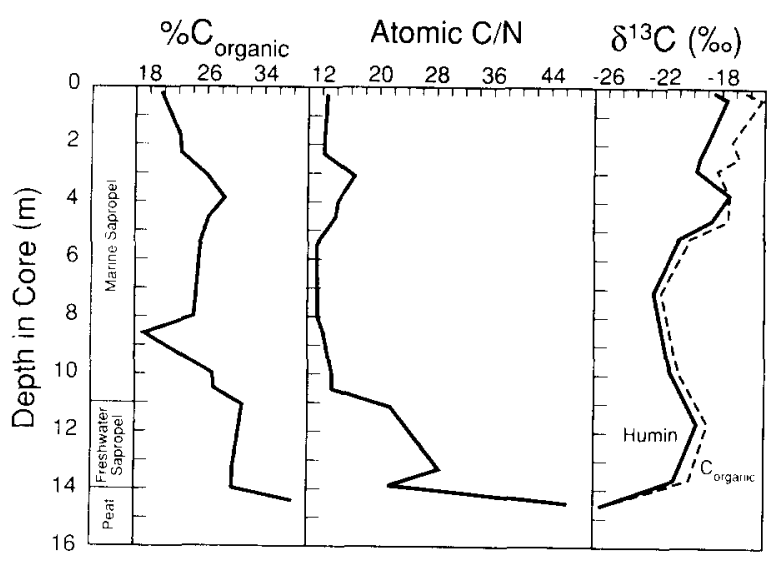

Fig. 3. Organic carbon concentrations, atomic $\mathrm{C} / \mathrm{N}$ ratios and carbon isotopic signatures of sediments from Mangrove Lake, Bermuda. From Hatcher et al. (1982) and Spiker and Hatcher (1984)
Mangrove Lake. The values are between 11 and 17 in the marine sapropel, between 22 and 28 in the freshwater sapropel, and between 22 and 46 in the peat layer (Fig. 3 ). The $\mathrm{C} / \mathrm{N}$ ratios indicate that the organic matter in the sapropels is a mix of vascular plant debris and algal plus bacterial remains which changes in the three types of sediment. Diagenetic alterations have not obliterated the general information about organic matter sources in the multi-kyr record of these sediments.

Comparison of the $\delta^{13} \mathrm{C}$ ratios of total organic carbon and of the humin fraction of sediment organic matter shows a downcore convergence in isotopic values (Fig. 3). This shift apparently is caused at least partly by selective loss of the isotopically heavy carbohydrate fraction of total organic matter (Spiker and Hatcher, 1984), but changes in the proportion of land-derived and marine-derived organic matter may also contribute. The possible diagenetic shift in the carbon isotope values is $\sim-2 \%$ over the multi-kyr age of these sediments. This value is essentially identical to the isotopic shift estimated by Hayes et al. (1989) in organic matter from the 91-Myrold Greenhorn Formation, Kansas, U.S.A. Despite the possibility of a diagenetic overprint on the isotopic compositions, the overall change in humin $\delta^{13} \mathrm{C}$-values from $-26 \%$ in the peat layer to $-18 \%$ at the sediment surface clearly reflects a change from land plants to marine algae as the major source of organic matter in Mangrove Lake.

\subsection{Sedimentary organic matter record in Lake Baikal (Siberia, Russia)}

Lake Baikal in southeastern Siberia is renowned for its great depth and ancient geological age. A sediment core from the northern basin provides a record of the last $\sim 9 \mathrm{kyr}$, which includes retreat of montane glaciers and establishment of forests in the catchment area (Qiu et al., 1993). The sediment layers reflect this sequence, and the $\mathrm{C} / \mathrm{N}$ ratios and $\delta^{13} \mathrm{C}$-values show changes in organic matter sources that accompany this paleoenvironmental succession (Fig. 4). 


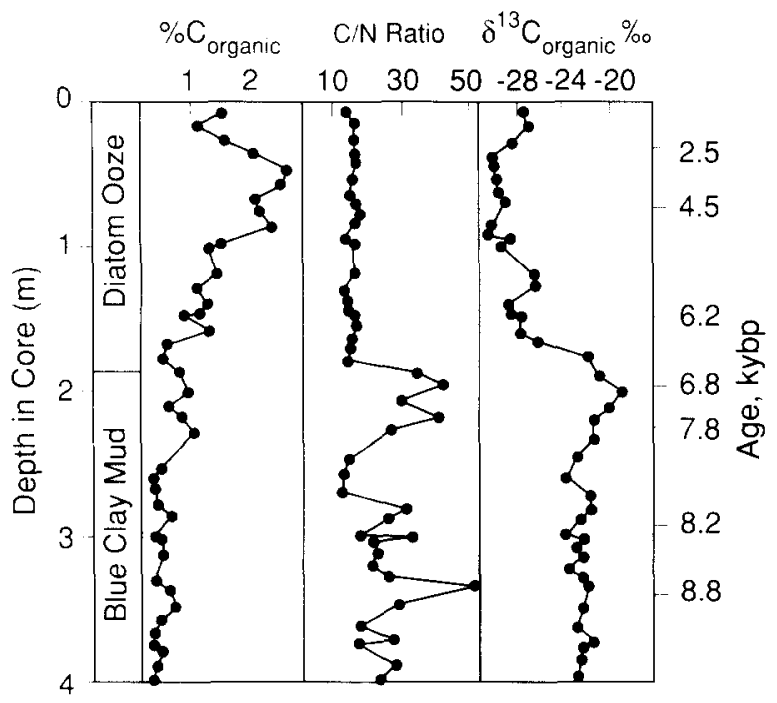

Fig. 4. Organic carbon concentrations, atomic $\mathrm{C} / \mathrm{N}$ ratios and carbon isotopic signatures of sediments from Lake Baikal, Siberia. From Qiu et al. (1993).

$\mathrm{C} / \mathrm{N}$-values in the postglacial blue clay muds deposited before $6.5 \mathrm{kyr}$ ago vary between 15 and 50 , and indicate substantial contributions of vascular land-plant material (Fig. 4). They vary little from $\sim 15$ in the diatom ooze that has accumulated since $6.5 \mathrm{kyr}$ ago. The change in sediment type from one dominated by glacial flour to one made up of algal material indicates that lake productivity increased at $\sim 6.5 \mathrm{kyr}$ ago, and this conclusion is strengthened by an increase in sediment organic carbon concentrations (Fig. 4). The drop in more recent $\mathrm{C} / \mathrm{N}$ ratios indicates that algal organic matter became a larger component of sediment organic matter at this transition.

Organic carbon $\delta^{13} \mathrm{C}$-values change from $-23 \%$ in sediments laid down before $6.5 \mathrm{kyr}$ ago to $\sim-28$ since that time. The increase in lake productivity is associated with the advent of a forested watershed (Qiu et al., 1993), and organic matter derived from these plants probably has accumulated in the lake sediments since this time. The isotopic signatures of $C_{3}$ land plants cannot be distinguished from those of freshwater algae, unlike the $\mathrm{C} / \mathrm{N}$ ratios (Table 1 ). The change in isotope ratios probably indicates a change in watershed vegetation from $\mathrm{C}_{4}$ tundra grasses to $C_{3}$ woody plants (Fig. 1). Both the elemental and isotopic ratios show that the sediment organic matter is a mixture of lake and land material, and they preserve a record of change in the relative proportions of algal and land-derived organic matter from several sources in this lake.

\subsection{Sedimentary organic matter record in Lake Bosumtwi (Ghana)}

Lake Bosumtwi occupies a meteorite impact crater in a low-lying region of Ghana and is consequently a relatively shallow ( $78 \mathrm{~m}$ max.), broad ( $8-\mathrm{km}$ diameter) lake having no outflow and a rather small watershed. The lake is permanently anoxic, and climate variations have caused the lake level to both rise and fall in the past (Talbot and Johannessen, 1992). Tropical forests cover the land around the lake today; savannas were dominant during drier climates of the past. A $17-\mathrm{m}$ sediment core from the deepest part of the lake provides a history of organic matter accumulation over the past $27.4 \mathrm{kyr}$. The core is divided into four major layers (Fig. 5), which indicate that important changes have occurred in the lake ecosystem over this time.

Organic matter $\mathrm{C} / \mathrm{N}$ ratios fluctuate markedly over the sedimentary history of Lake Bosumtwi (Fig. 5). The existence of values ranging between 15 and 35 in closely spaced sediment intervals, combined with no downcore trend to

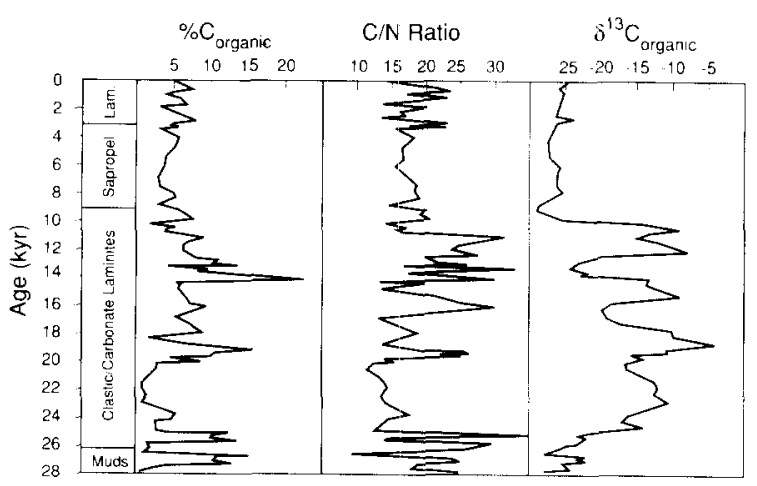

Fig. 5. Organic carbon concentrations, atomic $\mathrm{C} / \mathrm{N}$ ratios and carbon isotopic signatures of sediments from Lake Bosumtwi, Ghana. From Talbot and Johannessen (1992). 
higher or lower values, suggests that selective diagenesis has not had any major effect on organic matter $\mathrm{C} / \mathrm{N}$ ratios in sediments as old as $27.4 \mathrm{kyr}$ in this lake. The variations occur principally in laminated intervals and record changes in the delivery of land-derived organic matter to the lake sediments as climate conditions changed. Least variation is found in the sapropel layer, which represents a relatively stable period of high lake level, forested watershed and wetter climate (Talbot and Johannessen, 1992). The transition to this more stable interval occurs in the early Holocene (Fig. 5).

Organic carbon $\delta^{13} \mathrm{C}$-values record changes in the types of land vegetation around Lake Bosumtwi. The heavier values in the mixed clastic/ carbonate laminated sediments (Fig. 5) reflect contributions from $\mathrm{C}_{4}$ plants that lived during the drier conditions that existed near the end of the last glacial maximum 25 to $10 \mathrm{kyr}$ ago (Talbot and Johannessen, 1992). Values $\sim-25 \%$ in the deep muds and in the upper sediment layers indicate delivery of organic matter from $\mathrm{C}_{3}$ land plants that were present during wetter, forested parts of the lake history. Talbot and Johannessen (1992) consider possible diagenetic alteration of the carbon isotope record and conclude from several lines of evidence that it is minimal. The $\delta^{13} \mathrm{C}$ record of this lake is evidently dominated by changes in sources of organic matter.

\subsection{Sedimentary organic matter record in Lake Biwa (Japan)}

Sediments from Lake Biwa, Japan, provide a unique opportunity to investigate changes in organic matter sources and diagenesis over a long period of time. Five lithologic units were recovered by drilling in 1982/1983, totaling $911 \mathrm{~m}$ of sediments which overlie Paleozoic-Mesozoic basement rocks (Takemura, 1990). The oldest of these units is Pliocene in age. The downward sequence consists of: (1) the T Bed, a $250-\mathrm{m}$ thick unit composed of lacustrine deep-water clays; (2) the S Bed, a 332-m-thick unit containing alternations of shallow-water sands and silts; (3) the R Bed, a 150-m-thick unit made up of clay, sand and gravel subunits representing fluc- tuating deep and shallow depositional conditions; (4) the Q Bed, a 72-m-thick unit composed of layers of silt, sand and gravel laid down under shallow lacustrine or fluvial conditions; and (5) the P Bed, a 107-m-thick unit containing poorly sorted pebbles and gravels representing a fluviodeltaic environment. The basal age of the T Bed is estimated to be $0.43 \mathrm{Myr}$ (Meyers et al., 1993), and fission-track dating gives an age of $2.4 \mathrm{Myr}$ at $681 \mathrm{~m}$ in the R Bed (Takemura, 1990). The different sediment types record stages in the development of the lake which may have associated changes in sources of organic matter.

Accumulation of organic matter was fairly uniform over the entire history of the upper clay layer ( $\mathrm{T}$ Bed); organic carbon concentrations are generally between $0.5 \%$ and $1 \%$, and $\mathrm{C} / \mathrm{N}$ ratios remain about 10 (Fig. 6). In the sand and silt layer ( $\mathrm{S}$ Bed), organic carbon values are more variable, but on average slightly lower. $\mathrm{C} / \mathrm{N}$ ratios also vary considerable; their higher values indicate episodes of greater delivery of land-plant matter. The change in $\mathrm{C} / \mathrm{N}$ pattern at the $250-\mathrm{m}$ core depth records a shift from aquatic plant dominance in younger sediments to greater input of land-plant contributions in organic matter deposited previous to $0.43 \mathrm{Myr}$ ago. This interpretation is consistent with a change in sediment types from fine-grained deep-water sediment to shallow-water sands and gravels at the $250-\mathrm{m}$ depth. $\mathrm{C} / \mathrm{N}$-values return to values like those in

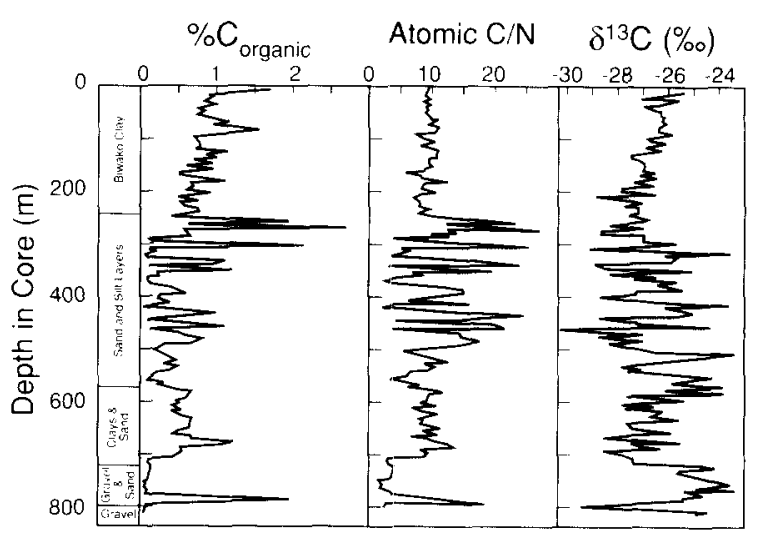

Fig. 6. Organic carbon concentrations, atomic $\mathrm{C} / \mathrm{N}$ ratios and carbon isotopic signatures of sediments from Lake Biwa, Japan. From Nakai (1972) and Ishiwatari and Uzaki (1987). 
the upper clays in the deep-water clay-sand alternations of the R Bed, and organic carbon concentrations are similar to those in the base of the upper clay layer (Fig. 6). $\mathrm{C} / \mathrm{N}$ ratios appear to preserve the differences between land-plant and algal sources of organic matter even in these 2.4Myr-old sediments.

Organic carbon $\delta^{13} \mathrm{C}$-values change from $-25.5 \%$ in near-surface sediments to $\sim-28 \% 0$ at $250-\mathrm{m}$ depth. A progressive change in organic matter source or diagenesis is not evident from $\mathrm{C} / \mathrm{N}$ ratios, which remain virtually unchanged (Fig. 6). Nakai (1972) has postulated that the local climate has become progressively warmer over the past $0.4 \mathrm{Myr}$, warming the surface waters of the lake and decreasing the kinetic isotopic fractionation by algae, but the pollen record does not indicate a progressive warming of the region. Progressively greater rates of algal productivity would also decrease their isotopic fractionation by limiting the availability of $\mathrm{CO}_{2}$ dissolved in the lake waters. The trend to lower organic carbon concentrations in older sediments suggests that there has in fact been a change in the rate of algal production over the 4.3-Myr history of the $\mathrm{T}$ Bed. A similar pattern of decreasing organic carbon burial and accompanying change in isotopic fractionation with sediment depth has been reported for Lake Ontario, North America (Schelske and Hodell, 1991), but this change in algal productivity occurred over the past century as a result of clear-cutting of the Ontario watershed. A different explanation is needed for the vastly different time-scale of the Lake Biwa change, and this explanation remains to be found.

Carbon isotope ratios are highly variable in the alternating sediment types below the upper clay (Fig. 6). Like the $\mathrm{C} / \mathrm{N}$ ratios, this variability may result from changes in the proportions of lakeand land-derived organic matter if there were changes in the proportions of $\mathrm{C}_{3}$ and $\mathrm{C}_{4}$ plants, as well. The range of variation is much smaller, however, than those in Lake Baikal and Lake Bosumtwi (Figs. 4 and 5), where changes in watershed organic matter sources from $C_{3}$ to $C_{4}$ plant dominance are recorded, thereby ruling out this effect. Because the heaviest isotope values generally coincide with the lowest $\mathrm{C} / \mathrm{N}$ ratios
(Fig. 6), algal productivity fluctuations are the most likely cause. The Lake Biwa isotope record appears to preserve intriguing and tantalizing paleolimnological information which awaits satisfactory interpretation.

\section{Organic matter source records in marine sediments}

The organic matter in marine sediments typically accumulates at slower rates and over longer periods of time than in lake sediments. It consequently has the potential to record longer paleoceanographic histories and to reveal the effects of slow-acting diagenetic alterations that are not evident in lake sediments. Marine algae are isotopically heavier than $\mathrm{C}_{3}$ land plants (Table 1; Fig. 1), so organic carbon isotopic compositions can be used to distinguish algal and land-plant contributions in marine sediments.

\subsection{Record of source changes at DSDP Site 619 (northern Gulf of Mexico)}

Deep Sea Drilling Project (DSDP) Site 619 is located at $2259-\mathrm{m}$ water depth in the Pygmy Basin on the continental shelf of the northern Gulf of Mexico. This oxic basin is a trap for continental and coastal marine sediments. The 209 $\mathrm{m}$ core of sediment from this site represents the last $\sim 0.1 \mathrm{Myr}$ of deposition and includes the most recent glacial-interglacial transition.

Concentrations of total organic carbon generally remain between $0.5 \%$ and $1.0 \%$, but a significant enhancement is present in sediments deposited between 25 and $8 \mathrm{kyr}$ ago (Fig. 7). This maximum zone roughly corresponds to maximum $\mathrm{C} / \mathrm{N}$ ratios and minimum $\delta^{13} \mathrm{C}$-values (Fig. 7). These patterns have been interpreted by Jasper and Gagosian (1990) to represent a record of changes in the proportional contributions of land-derived and algal organic matter. During the last glacial sealevel lowstand ( 25 to $10 \mathrm{kyr}$ ago ), continental organic matter from the Mississippi River in North America dominated accumulation at this location. Sediments deposited before 90 and after $10 \mathrm{kyr}$ ago contain larger 


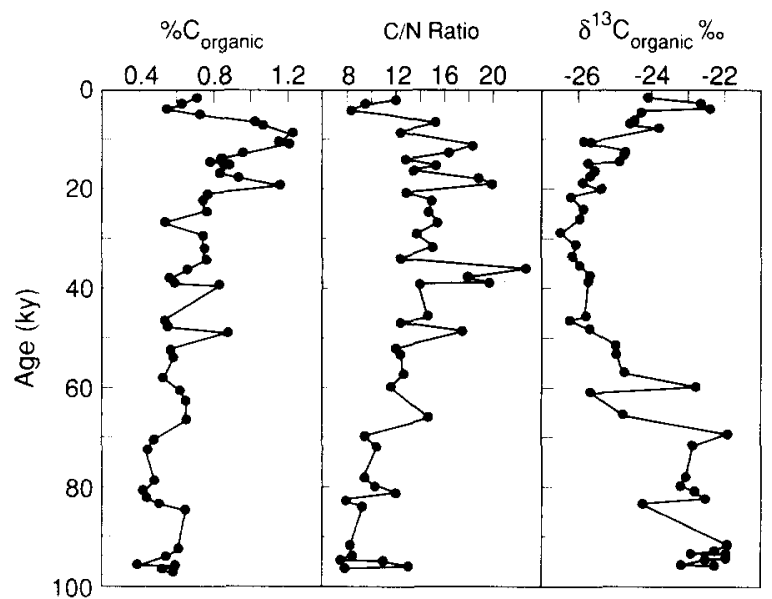

Fig. 7. Glacial-interglacial changes in organic carbon concentrations, atomic $\mathrm{C} / \mathrm{N}$ ratios and carbon isotopic signatures of sediments from DSDP Site 619 in the Pygmy Basin, northern Gulf of Mexico. Data adapted from Jasper and Gagosian (1990).

proportions of marine organic matter.

The $\mathrm{C} / \mathrm{N}$ and carbon isotopic ratios appear to record the organic matter source changes reliably, yet in situ degradation of sedimentary organic matter is evident from biomarker analyses (Jasper and Gagosian, 1993). Both sulfate-reducing and methanogenic bacteria are active in these sediments. Pore water sulfate diminishes with depth, and this trend is presumably accompanied by organic carbon oxidation. Methane with $\delta^{13} \mathrm{C}$-values between $-95 \% 0$ and $-72 \% 0$ is present in sediments at depths of 76-178 m and signifies active microbial populations. Jasper and Gagosian (1990) noted that concentrations of organic carbon seem to diminish following a firstorder decay. Deeper concentrations are indeed less than those in the upper sediments (Fig. 7), but much of this pattern reflects addition of continental organic matter during the last glacial lowstand to a low background of marine organic matter and probably not postdepositional degradation. The indirect evidence of microbial activity strongly indicates that organic matter is being destroyed deep in the sediments, but probably not at high rates. Fluctuations in organic carbon concentrations appear to record varia- tions in initial deposition rather than variations in diagenetic destruction of organic matter. The important conclusion is that organic matter source signatures are preserved in the elemental and isotopic compositions of Site 619 sediments despite evidence of continued, postdepositional microbial activity.

\subsection{Record of fluctuations in marine productivity at DSDP Site 532 (Walvis Ridge, South Atlantic)}

Sediments in DSDP Site 532 on the continental terrace of the Walvis Ridge, southwest African margin, record the history of enhanced marine productivity associated with the Benguela Current upwelling system. Upwelling was initiated $\sim 10$ Myr ago (Siesser, 1980) and has gradually increased since that time. Site 532 sediments are diatom-rich calcareous oozes, and they typically contain light-dark variations in color and carbonate concentrations which are believed to represent Milankovitch-type fluctuations in marine productivity (Diester-Haass et al., 1992).

Organic carbon concentrations in sediments from near the Plio-Pleistocene boundary are $\sim 4 \%$ in dark-colored intervals in which carbonate concentrations are depressed and $\sim 2 \%$ in

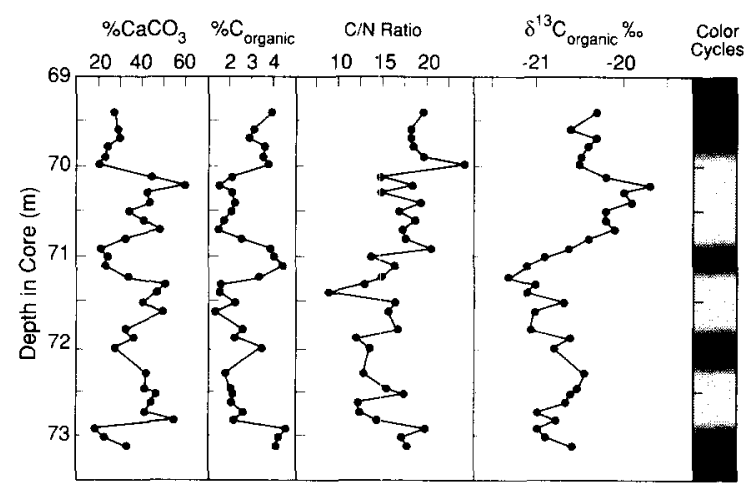

Fig. 8. Calcium carbonate and organic carbon concentrations, atomic $\mathrm{C} / \mathrm{N}$ ratios, and carbon isotopic signatures of sediments from DSDP Site 532, Walvis Ridge, South Atlantic Ocean. From Meyers (1992). 
light-colored, carbonate-rich intervals (Fig. 8). The inverse relationship between organic and inorganic carbon reflects varying dissolution of the $\mathrm{CaCO}_{3}$ by dissolved $\mathrm{CO}_{2}$ generated by oxidation of organic carbon (Diester-Haass et al., 1992). As noted also in the sediments of DSDP Site 619, the presence of abundant sub-bottom methane and $\mathrm{CO}_{2}$ implies that methanogenic bacteria are actively degrading organic matter throughout the Site 532 sediments (Meyers and Brassell, 1985).

Variations in organic $\mathrm{C} / \mathrm{N}$ - and $\delta^{13} \mathrm{C}$-values do not follow the organic carbon pattern, yet they seem to be related (Fig. 8). The isotopic values fall nicely within the range of marine algae, but the $\mathrm{C} / \mathrm{N}$ ratios are much higher than expected for algal organic matter (Table 1). Neither of these potential source identifiers appears to be affected by the postulated variations in oxidation of organic matter reflected in the light-dark cycles (Fig. 8) or by the general degradation of organic matter indicated by biogenic gases.

The elevated $\mathrm{C} / \mathrm{N}$ ratios would normally indicate that an important proportion of landplant-derived organic matter is contained in these sediments, but several types of evidence contradict this conclusion: (1) the sediments are biogenic oozes with little clastic input; (2) the coastal Namib Desert is sparsely vegetated and can provide little organic matter; (3) the isotopic values indicate a marine algal source of organic matter; and (4) Rock-Eval ${ }^{\circledR}$ analyses of the sedimentary organic matter confirm a predominantly marine origin (Meyers et al., 1984b). The elevated $\mathrm{C} / \mathrm{N}$ ratios might accompany high rates of marine productivity, possibly under conditions of limited nitrogen availability (Meyers, 1992). The organic matter produced under such conditions would be lipid-rich and nitrogen-poor, thereby having higher than expected $\mathrm{C} / \mathrm{N}$ ratios. High productivity typically diminishes isotopic discrimination in algae (cf. Schelske and Hodell, 1991 ) and leads to heavier $\delta 13 \mathrm{C}$-values, which are in fact found associated with elevated $\mathrm{C} / \mathrm{N}$ ratios in the Plio-Pleistocene Site 532 sediments (Fig. 8). The similarities between the $\mathrm{C} / \mathrm{N}$ and $\delta{ }^{13} \mathrm{C}$ profiles may record productivity variations which are independent of the light-dark cycles in these upwelling sediments.

\subsection{Organic matter record of high-latitude} marine productivity at ODP Site 689 (Maude Rise, South Atlantic)

Ocean Drilling Program (ODP) Site 689 is located in $2083 \mathrm{~m}$ of water on the crest of the Maude Rise $\sim 500 \mathrm{~km}$ north of Antarctica. Sediments are biogenic oozes and typically contain $\geqslant 90 \% \mathrm{CaCO}_{3}$. They accumulated slowly; the paleoceanographic record of nearly all of the Tertiary and Quaternary (65 Myr) is represented by $250 \mathrm{~m}$ of sediment. Accumulation rates have, however, accelerated since the Miocene-Pliocene boundary. Sediments from the entire Miocene (20 Myr) are equal in thickness to sediments from the Pliocene ( $3 \mathrm{Myr}$ ).

Organic carbon concentrations are low $(\sim 0.1 \%)$ throughout the $250-\mathrm{m}$ sediment record at Site 689 (Fig. 9), reflecting low sedimentation rates and low marine productivity (Macko and Pereira, 1990). The higher sedimentation rates evident from the thickness of the Pliocene and Pleistocene units indicate that organic matter mass accumulation rates must have increased since the Miocene. $\mathrm{C} / \mathrm{N}$ ratios are generally low, and the frequent spikes in $\mathrm{C} / \mathrm{N}$ ratios are enigmatic (Macko and Pereira, 1990). They may record variations in diagenetic alterations of algal organic matter $(\mathrm{C} / \mathrm{N} \approx 5)$ in which $\mathrm{CO}_{2}$ would

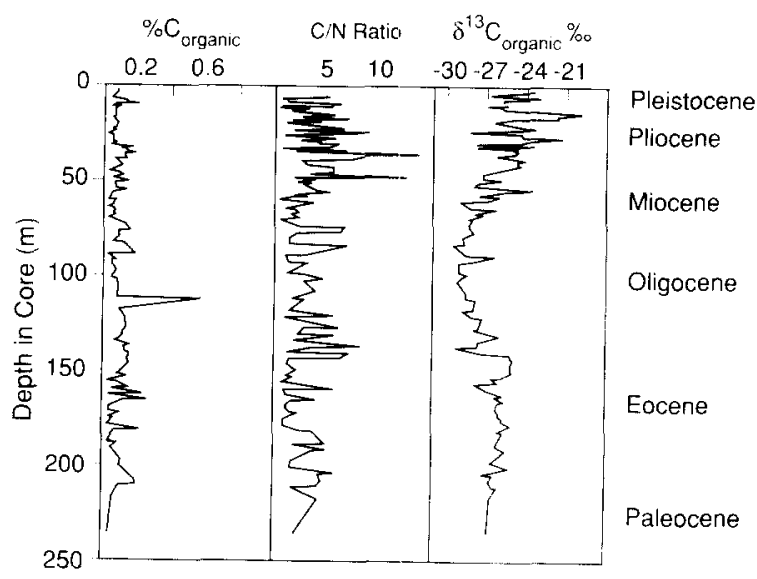

Fig. 9. Organic carbon concentrations, atomic $\mathrm{C} / \mathrm{N}$ ratios and carbon isotopic signatures of sediments from ODP Site 689 , Maude Rise, Antarctic Margin. From Macko and Pereira (1990) 
diffuse away whereas ammonium nitrogen would remain trapped in the sediments (Müller, 1977).

Organic carbon $\delta^{13} \mathrm{C}$-values are relatively light for marine plankton (Table 1 ), yet they are unlikely to represent delivery of land-derived organic matter from ice-covered Antarctica. Rau et al. (1989) have shown that cold polar seawater can accommodate substantially more dissolved $\mathrm{CO}_{2}$ than temperate or tropical waters, thereby permitting greater isotopic discrimination by algae. The $\delta^{13} \mathrm{C}$-values of $\sim-27 \%$ suggest that cool conditions prevailed over Site 619 through most of the Tertiary even though a permanent ice sheet did not develop on Antarctica until 35 Myr ago (Kennett, 1977). Variability increases in $\delta^{13} \mathrm{C}$-values in sediments deposited since the Middle Miocene and values in general become heavier (Fig. 9). These changes in isotopic composition but not in $\mathrm{C} / \mathrm{N}$ ratios suggest that marine productivity rates increased, although not smoothly, towards present conditions. The Site 689 sediments evidently preserve a record of organic matter production for the past $60 \mathrm{Myr}$, even though substantial recycling of the organic matter has occurred before and after deposition.

\subsection{Record of marine organic matter accumulation at ODP Site 805 (Ontong Java Plateau, north Pacific)}

ODP Site 805 is located under the North Pacific Ocean equatorial upwelling zone in $3188-\mathrm{m}$ water depth on the Ontong Java Plateau. Sediments are a nannofossil ooze $\left(\sim 90 \% \mathrm{CaCO}_{3}\right)$ throughout the Neogene-Quaternary sections recovered at this location.

Concentrations of organic carbon are very low $(<0.05 \%)$ in sediments deposited between 25 and $6 \mathrm{Myr}$ ago and increase to $\sim 0.1 \%$ since 5 Myr ago (Fig. 10). Calculated mass accumulation rates imply that greater delivery of organic matter, not simply improved preservation at the seafloor, is responsible for the higher concentrations (Stax and Stein, 1993). The enhanced delivery may arise from higher rates of marine organic matter production, from addition of landderived organic matter, or from a general increase in total sediment accumulation. $\mathrm{C} / \mathrm{N}$ ra-

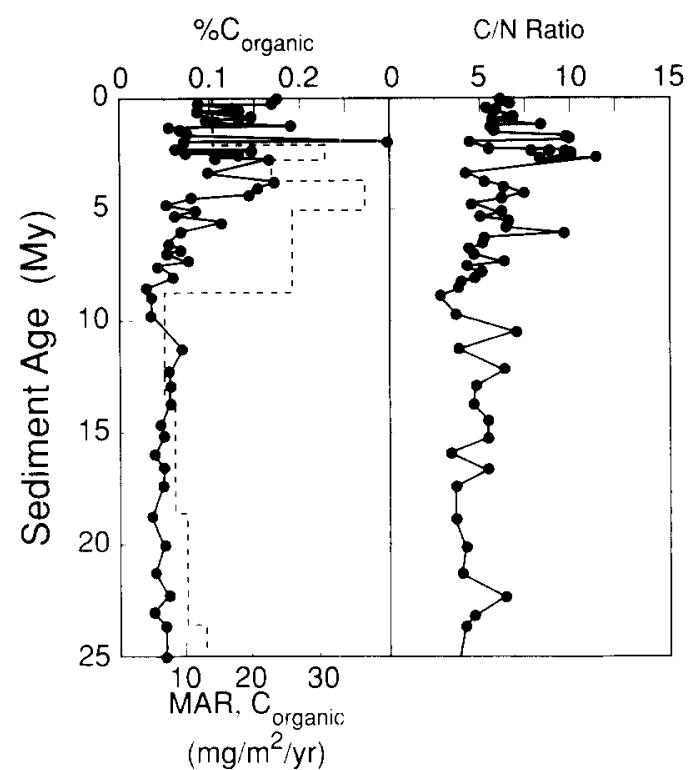

Fig. 10. Organic carbon concentrations and atomic $\mathrm{C} / \mathrm{N}$ ratios of sediments from ODP Site 805 , Ontong Java Plateau, central Pacific Ocean. Organic carbon mass accumulation rates (MAR) indicated by dotted line. From Stax and Stein (1993).

tios remain between 5 and 10 throughout the core and indicate a predominantly marine origin for the sedimentary organic matter, eliminating major additions of continental material as a possible explanation. Moreover, the dominance of marine material agrees with the sediment character. Estimated paleoproductivities in the upper and lower parts of the cored sediment record are the same $\left(\sim 38 \mathrm{~g} \mathrm{~m}^{-2} \mathrm{yr}^{-1} \mathrm{C}\right)$ and are somewhat lower than an estimate of modern productivity $\left(45 \mathrm{~g} \mathrm{~m}^{-2} \mathrm{yr}^{-1} \mathrm{C}\right)$ based on the concentration of organic carbon in surficial sediments (Stax and Stein, 1993). A change in productivity is consequently not evident from the organic carbon data. The enhanced accumulation of organic carbon peaking at $5 \mathrm{Myr}$ ago may arise from increased accumulation of the biogenic sediments and may therefore be indirect evidence of increased productivity. Organic matter in the Site- 805 sediments does not in itself preserve a history of equatorial upwelling, even though it preserves a marine source character. Probable variations in the degradation of marine organic matter during its sinking to the depth of this site 
appears to introduce uncertainties into estimates of surface productivity rates. The sediment record at this location shows that quantitative use of organic matter must be done cautiously, inasmuch as preservation can be variable.

\subsection{Record of increased continental sediment input to DSDP Site 443 (north Philippine Sea)}

DSDP Site 443 is located in the Shikoku Basin south of Japan. Sediments from this site are hemipelagic, and their accumulation rate has increased since $2 \mathrm{Myr}$ ago (Fig. 11). Organic carbon concentrations are generally $\sim 0.1 \%$, but increase to $\sim 0.3-0.4 \%$ in sediments deposited during the past $1 \mathrm{Myr}$. $\mathrm{C} / \mathrm{N}$ ratios change from $\sim 5$ to $\sim 10$ as the organic carbon concentrations increase (Fig. 11).

The changes in organic carbon concentration and in $\mathrm{C} / \mathrm{N}$ ratios were interpreted by Waples and Sloan (1980) as evidence of continuing diagenesis of organic matter over multi-Myr time periods. They postulated that nitrogen-containing organic compounds were protected by association with mineral particles whereas carbonrich organic matter components gradually were decomposed. Subsequent inferential evidence of microbial activity to depths of several hundreds of meters in marine sediments supports this hy-

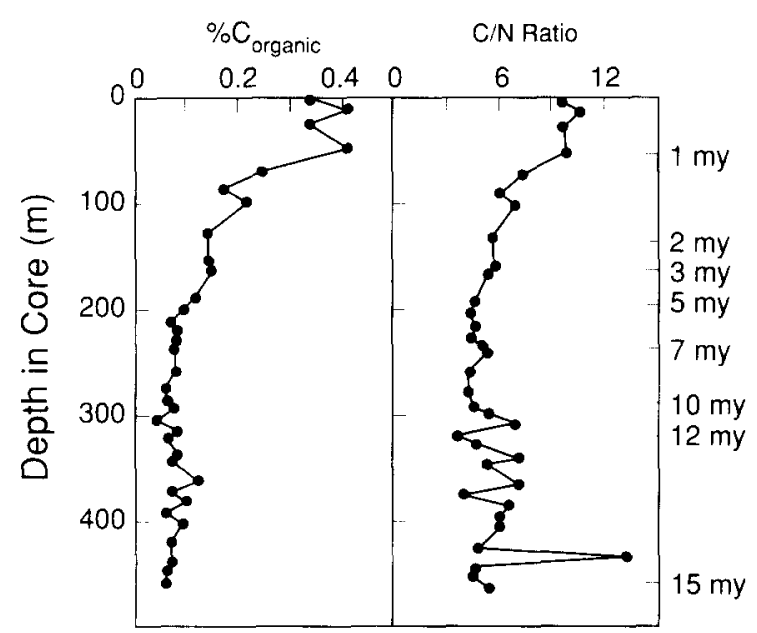

Fig. 11. Organic carbon concentrations, atomic $\mathrm{C} / \mathrm{N}$ ratios of sediments from DSDP Site 443, Bonin Basin, western Pacific Ocean. From Waples and Sloan (1980). pothesis (e.g., Meyers and Brassell, 1985; Jasper and Gagosian, 1990, 1993).

An alternate possibility, however, seems more plausible given the lack of evidence of continued loss of marine organic carbon from Sites 689 and 805 in sediments that are older than those at Site 443. It is probable that the increases in sedimentation rate, organic carbon concentration, and $\mathrm{C} / \mathrm{N}$ ratios in sediments deposited since $\sim 1 \mathrm{Myr}$ ago record enhanced contribution of continental sediments and their associated organic matter. A very likely source of these sediments is the Huang Ho, which drains much of China north of the Himalaya. Since the onset of northern hemisphere glaciation during the Pliocene, sediment loads of rivers have been delivered directly to the deep basins of the oceans during glacial sealevel lowstands, thereby increasing hemipelagic sedimentation rates. The Huang Ho would empty into the western Pacific Ocean very near the Shikoku Basin during lowstands. Cellulose-rich continental organic matter is typically less degradable than algal organic matter, and it has a higher $\mathrm{C} / \mathrm{N}$ ratio (Table 1 ). The changes in organic matter amount and type at Site 443 are probably similar in origin to those at Site 619 in the Pygmy Basin, where glacial-age sediments are enriched by continental organic matter. Consequently, the $\mathrm{C} / \mathrm{N}$ profile may preserve a record of source change and not a diagenetic effect.

\section{Summary and conclusions}

An overview of changes in the amounts and compositions of organic matter collected in sediment traps and present in sediments of lakes and oceans allows some general conclusions about the preservation of source indicators:

(1) Only a small fraction of the original organic matter produced in the photic zone survives destruction and alteration during sinking and sedimentation in lakes and oceans.

(2) Biomarker molecules indicative of algal organic matter sources are preferentially destroyed, thereby biasing the molecular source character of sedimentary organic matter towards land plants. 
(3) The $\mathrm{C} / \mathrm{N}$ and carbon isotope compositions of organic matter from several broad classes of plants can be used in tandem to distinguish between organic matter from freshwater algae, marine algae, continental $\mathrm{C}_{3}$ plants and continental $\mathrm{C}_{4}$ plants.

(4) The $\mathrm{C} / \mathrm{N}$ - and $\delta^{13} \mathrm{C}$-values of total organic matter appear to retain source signatures which, despite some possible early diagenetic modifications, remain intact for million-year time periods.

(5) The possible consequences of diagenesis must always be judiciously considered when making organic matter source estimates. Sedimentary matrices provide important information about the reasonableness of source estimates based on organic constituents.

\section{Acknowledgments}

I thank Cindy Lee for offering me the opportunity to organize and present the thoughts presented in this paper. Her comments, and those of two anonymous reviewers, helped to refine them. Acknowledgment is made to the donors of the Petroleum Research Fund, administered by the American Chemical Society, for partial support of this research.

\section{References}

Benson, L.V., Meyers, P.A. and Spencer, R.J., 1991. Change in the size of Walker Lake during the past 5000 years. Palaeogeogr., Palaeoclimatol., Palaeoecol., 81: 189-214.

Diester-Haass, L., Meyers, P.A. and Rothe, P., 1992. Neogene-Quaternary history of the Benguela Current and associated upwelling on the southwest African margin (DSDP Sites 362 and 532). In: C.P. Summerhayes, W.L. Prell and K.C. Emeis (Editors), Evolution of Upwelling Systems Since the Early Miocene. The Geological Society, Bath, pp. 331-342.

Eadie, B.J., Chambers, R.L., Gardner, W.S. and Bell, G.L., 1984. Sediment trap studies in Lake Michigan: resuspension and chemical fluxes in the southern basin. J. Great Lakes Res., 10: 307-321.

Emerson, S. and Hedges, J.I., 1988. Processes controlling the organic carbon content of open ocean sediments. Paleoceanography, 3: 621-634.

Ertel, J.R. and Hedges, J.I., 1985. Sources of sedimentary humic substances: vascular plant debris. Geochim. Cosmochim. Acta, 49: 2097-2107.

Fry, B., Scalan, R.S. and Parker, P.L., 1977. Stable carbon isotope evidence for two sources of organic matter in coastal sediments: seagrasses and plankton. Geochim. Cosmochim. Acta, 41: 1875-1877.

Gearing, J.N., Gearing, P.J., Rudnick, D.T., Requejo, A.G. and Hutchins, M.J., 1984. Isotopic variability of organic carbon in a phytoplankton-based, temperate estuary. Geochim. Cosmochim. Acta, 48: 1089-1098.

Gearing, P.J., Plucker, F.E. and Parker, P.L., 1977. Organic carbon stable isotope ratios of continental margin sediments. Mar. Chem., 5: 251-266.

Goossens, H., Duren, R.R., de Leeuw, J.W. and Schenck, P.A., 1989. Lipids and their mode of occurrence in bacteria and sediments, II. Lipids in the sediment of a stratified, freshwater lake. Org. Geochem., 14: 27-41.

Hatcher, P.G., Simoneit, B.R.T., Mackenzie, F.T., Neumann, A.C., Thorstenson, D.C. and Gerchakov, S.M., 1982. Organic geochemistry and pore water chemistry of sediments from Mangrove Lake, Bermuda. Org. Geochem., 4: 93-112.

Hayes, J.M., Popp, B.N., Takigiku, R. and Johnson, M.W., 1989. An isotopic study of biogeochemical relationships between carbonates and organic carbon in the Greenhorn Formation. Geochim. Cosmochim. Acta, 53: 2961-2972.

Hunt, J.M., 1970. The significance of carbon isotope variations in marine sediments. In: G.D. Hobson and G.C. Spears (Editors), Advances in Organic Geochemistry, 1966. Pergamon, Oxford, pp. 27-35.

Ishiwatari, R. and Uzaki, M., 1987. Diagenetic changes of lignin compounds in a more than 0.6 million-year-old lacustrine sediment (Lake Biwa, Japan). Geochim. Cosmochim. Acta, 51: 321-328.

Jasper, J.P. and Gagosian, R.B., 1990. The sources and deposition of organic matter in the Late Quaternary Pygmy Basin, Gulf of Mexico. Geochim. Cosmochim. Acta, 54: 117-1132.

Jasper, J.P. and Gagosian, R.B., 1993. The relationship between sedimentary organic carbon isotopic composition and organic biomarker compound concentration. Geochim. Cosmochim. Acta, 57: 167-186.

Kawamura, K., Ishiwatari, R. and Ogura, K., 1987. Early diagenesis of organic matter in the water column and sediments: Microbial degradation and resynthesis of lipids in Lake Haruna. Org. Geochem., 11: 251-264.

Kennett, J.P., 1977. Cenozoic evolution of Antarctic glaciation, the circum-Antarctic ocean, and their impact on global paleoceanography. J. Geophys. Res., 82: 38433859.

Knauer, G.A. and Martin, J.H., 1981. Primary production and carbon-nitrogen fluxes in the upper $1500 \mathrm{~m}$ of the northeast Pacific. Limnol. Oceanogr., 26: 181-186.

Macko, S.A. and Pereira, C.P.G., 1990. Neogene paleoclimate development of the Antarctic Weddell Sea region: Organic geochemistry. In: P.F. Barker, J.P. Kennett, et al. (Editors), Proceedings of the Ocean Drilling Program, 
Scientific Results, Vol. 113. Ocean Drill. Prog., College Station, Texas, pp. 881-893.

Meyers, P.A., 1990. Impacts of late Quaternary fluctuations in water level on the accumulation of sedimentary organic matter in Walker Lake, Nevada. Palaeogeogr., Palaeoclimatol., Palaeoecol., 78: 229-240.

Meyers, P.A., 1992. Organic matter variations in sediments from DSDP Sites 362 and 532: Evidence of upwelling changes associated with the Benguela Current. In: C.P. Summerhayes, W.L. Prell and K.C. Emeis (Editors), Evolution of Upwelling Systems Since the Early Miocene. The Geological Society, Bath, pp. 323-329.

Meyers, P.A. and Brassell, S.C., 1985. Biogenic gases in sediments deposited since Miocene times on the Walvis Ridge, South Atlantic Ocean. In: J.A. Brierly, D. Caldwell and C.L. Brierly (Editors), Planetary Ecology: Selected Papers from the Sixth International Symposium. Van Nostrand Reinhold, New York, N.Y., pp. 69-80.

Meyers, P.A. and Eadie, B.J., 1993. Sources, degradation and recycling of organic matter associated with sinking particles in Lake Michigan. Org. Geochem., 20: 47-56.

Meyers, P.A., Leenheer, M.J., Eadie, B.J. and Maule, S.J., 1984a. Organic geochemistry of suspended and settling particulate matter in Lake Michigan. Geochim. Cosmochim. Acta, 48: 443-452.

Meyers, P.A., Brassell, S.C. and Huc, A.Y., 1984b. Geochemistry of organic carbon in Leg 75 sediments. In: W.W. Hay, J.-C. Sibuet, et al. (Editors), Initial Reports of the Deep Sea Drilling Project, Vol. 75. U.S. Gov. Print. Off., Washington, D.C., pp. 967-981.

Meyers, P.A., Takemura, K. and Horie, S., 1993. A reinterpretation of Lake Quaternary sediment chronology of Lake Biwa, Japan, from correlation with marine glacial-interglacial cycles. Quat. Res., 39: 154-162.

Müller, P.J., 1977. C/N ratios in Pacific deep-sea sediments: Effect of inorganic ammonium and organic nitrogen compounds sorbed by clays. Geochim. Cosmochim. Acta, 41: $765-776$.

Nakai, N., 1972. Carbon isotopic variation and the paleoclimate of sediments from Lake Biwa. Proc. Jpn. Acad., 48: 516-521.

Newman, J.W., Parker, P.L. and Behrens, E.W., 1973. Organic carbon isotope ratios in Quaternary cores from the Gulf of Mexico. Geochim. Cosmochim. Acta, 37: 225238.

O'Leary, M.H., 1988. Carbon isotopes in photosynthesis. Bioscience, 38: 328-336.

Prahl, F.G., Bennett, J.T. and Carpenter, R., 1980. The early diagenesis of aliphatic hydrocarbons and organic matter in sedimentary particulates from Dabob Bay, Washington. Geochim. Cosmochim. Acta, 44: 1967-1976.

Premuzic, E.T., Benkovitz, C.M., Gaffney, J.S. and Walsh, J.J., 1982. The nature and distribution of organic matter in the surface sediments of world oceans and seas. Org. Geochem., 4: 63-77.
Qiu, L., Williams, D.F., Gvorzdkov, A., Karabanov, E. and Shimaraeva, M., 1993. Biogenic silica accumulation and paleoproductivity in the northern basin of Lake Baikal during the Holocene. Geology, 21: 25-28.

Rau, G.H., Takahashi, T. and Des Marais, D.J., 1989. Latitudinal variation in plankton $\delta^{13} \mathrm{C}$ : Implications for $\mathrm{CO}_{2}$ and productivity in past oceans. Nature (London), 341 : 516-518.

Rodelli, M.R., Gearing, J.N., Gearing, P.J., Marshall, N. and Sasekumar, A., 1984. Stable isotope ratio as a tracer of mangrove carbon in Malaysian ecosystem. Oecologia, 61: 326-333.

Schelske, C.L. and Hodell, D.A., 1991. Recent changes in productivity and climate of Lake Ontario detected by isotopic analysis of sediments. Limnol. Oceanogr., 36: 961975.

Siesser, W.G., 1980. Late Miocene origin of the Benguela Upwelling System of northern Namibia. Science, 208: 283-285.

Sollins, P., Spycher, G. and Glassman, C.A., 1984. Net nitrogen mineralization from light-fraction and heavy fraction forest soil organic matter. Soil Biol. Biochem., 16:31-37.

Spiker, E.C. and Hatcher, P.G., 1984. Carbon isotope fractionation of sapropelic organic matter during early diagenesis. Org. Geochem., 5: 293-290.

Stax, R. and Stein, R., 1993. Long term changes in accumulation of organic carbon in Neogene sediments of ODP Leg 130 (Ontong Java Plateau). In: W.H. Berger, L.W. Kronke, T.R. Janecek, et al. (Editors), Proceedings, Ocean Drilling Program, Scientific Results. Vol. 130. Ocean Drill. Prog., College Station, Texas, pp. 573-584.

Suess, E., 1980. Particulate organic carbon flux in the oceans - surface productivity and oxygen utilization. Nature (London), 288: 260-263.

Takemura, K., 1990. Tectonic and climatic record of the Lake Biwa, Japan, region, provided by sediments deposited since Pliocene times. Palaeogeogr.. Palaeoclimatol., Palaeoecol., 78: 185-193.

Talbot, M.R. and Johannessen, T., 1992. A high resolution palaeoclimatic record for the last 27,500 years in tropical West Africa from the carbon and nitrogen isotopic composition of lacustrine organic matter. Earth Planet. Sci. Lett., 110: 23-37.

Wakeham, S.G. and Lee, C., 1989. Organic geochemistry of particulate matter in the ocean: The role of particles in oceanic sedimentary cycles. Org. Geochem., 14: 83-96.

Wakeham, S.G., Farrington, J.W., Gagosian, R.B., Lee, C., De Baar, H., Nigrelli, G.E., Tripp, B.W., Smith, S.O. and Frew, N.M., 1980. Organic matter fluxes from sediment traps in the equatorial Atlantic Ocean. Nature (London), 286: 798-800.

Waples, D.W. and Sloan, J.R., 1980. Carbon and nitrogen diagenesis in deep sea sediments. Geochim. Cosmochim. Acta, 44: 1463-1470. 